\title{
Differences in Winter Browning among Japanese-cedar Cultivars Are Not Due to Variation in Ploidy Levels
}

\author{
Ryan N. Contreras ${ }^{1,4}$ \\ Department of Horticulture, Oregon State University, 4017 Agricultural \\ and Life Sciences Building, Corvallis, OR 97331-7304 \\ Ron Determann ${ }^{2}$ \\ Atlanta Botanical Garden, 1345 Piedmont Avenue NE, Atlanta, GA 30309 \\ Mara Friddle ${ }^{3}$ \\ Department of Horticulture, Oregon State University, 4017 Agricultural \\ and Life Sciences Building, Corvallis, OR 97331-7304
}

Additional index words. Cryptomeria japonica, flow cytometry, cytology, photoinhibition, carbol fuchsin, DAPI

\begin{abstract}
There is a great deal of variation among japanese-cedar cultivars with regard to growth form, foliar characteristics, and winter browning. Differences in winter browning have been observed and documented by a number of authors. Previous research has established that there are differences in winter foliage color between cultivars included in the current study; however, no quantitative analysis under standardized conditions was conducted. Because of a previous report that tetraploid forms of japanese-cedar remain green during winter as a result of increased antioxidant enzyme activity, we hypothesized that cultivars that exhibit reduced winter browning were polyploids. We screened 56 accessions of japanese-cedar using flow cytometry analysis of $4^{\prime}, 6$-diamidino-2-phenylindole (DAPI)-stained nuclei and performed chromosome counts on three cultivars. All accessions were diploid $(2 n=2 x=22)$, although there were significant differences in genome sizes among the cultivars. Holoploid genome sizes ranged from $18.9 \mathrm{pg}$ for var. sinensis JCRA to $22.3 \mathrm{pg}$ for 'Viridis' with a mean of $20.1 \mathrm{pg}$. Chromosome counts for cultivars Ogon, Oye Keme, and Viridis supported the flow cytometry results. Although the underlying cause of the variability in morphology and winter browning among cultivars is unclear, our results show that differences in ploidy level are not responsible, because all tested genotypes were diploid. Chemical name: 4',6-diamidino-2-phenylindole (DAPI).
\end{abstract}

Japanese-cedars (Cryptomeria japonica D. Don) are large trees in their native range of Japan and China and are often used as timber trees that may reach 36 to $46 \mathrm{~m}$ high in the wild (Dallimore and Jackson, 1967). In managed landscapes they are sometimes used as an alternative to leyland cypress [×Cuprocyparis leylandii (A.B. Jacks. \& Dallim.) Farjon (Farjon et al., 2002)]. They are tolerant of biotic and abiotic stresses (Tripp, 1993; Tripp and Raulston, 1992) and form attractive large screens or specimens in landscapes. However, winter browning caused by photoinhibition (Ida, 1981) is unsightly and likely has reduced the use of japanese-cedars. Winter browning occurs as

Received for publication 18 Aug. 2011. Accepted for publication 9 Sept. 2011.

We thank Shawn Mehlenbacher, Jim Myers, and anonymous colleagues for critical review of the manuscript.

${ }^{1}$ Assistant Professor.

${ }^{2}$ Conservatory and Conservation Director.

${ }^{3}$ Faculty Research Assistant.

${ }^{4}$ To whom reprint requests should be addressed; e-mail contrery@hort.oregonstate.edu. a result of the accumulation of the pigment rhodoxanthin during photoinhibitory conditions. Rhodoxanthin acts to protect the photosynthetic apparatus by dissipating excess light energy as heat to prevent the accumulation of reactive oxygen species (Han et al., 2003). Plants found in Japanese forestry nurseries that did not exhibit winter browning were identified as tetraploids (Chiba, 1951), and it was found that they did not accumulate rhodoxanthin because they were more resistant to the oxidative damage resulting from increased antioxidant levels (Niwa and Sasaki, 2003). Winter browning is highly variable among ornamental cultivars of japanese-cedar. Rouse et al. (2000) described 45 cultivars of japanesecedar growing in the eastern United States including variability in foliage color during winter from brown to dark green. Our hypothesis was that a difference in ploidy level among cultivars is related to the variation in winter color and that cultivars that remain greener during winter were tetraploids. The current study was conducted to determine the ploidy level of 56 accessions of japanese-cedar and if variation in ploidy level is related to variation in winter browning.
Plant material. Fifty-six accessions of Cryptomeria japonica were received from the Atlanta Botanical Garden (Atlanta, GA), JC Raulston Arboretum (Raleigh, NC), Hopper Bros. (Woodburn, OR), Bizon Nursery Company (Hubbard, OR), and Youngblood Nursery Inc. (Salem, OR) as unrooted stem cuttings, rooted cuttings, or containerized plants (Table 1). Material received as unrooted stem cuttings was rooted using $2000 \mathrm{ppm}$ indole 3butyric acid (Dip'N Grow ${ }^{\circledR}$; Dip'N Grow, Inc., Clackamas, OR), stuck into a 1 peat: 1 perlite substrate, and placed under mist at a rate of $10 \mathrm{~s}$ every $60 \mathrm{~min}$ until root formation. The 56 accessions included in the study were chosen based on availability as well as differences in winter browning. Included in Table 1 are observations of winter color for 33 accessions from the current study from Rouse et al. (2000). These data are included to demonstrate the variability of winter foliage color among japanese-cedar cultivars. Observations by Rouse et al. (2000) were made at multiple locations from Atlanta, GA, to Philadelphia, PA, over a 3-year period. Conditions were not standardized; therefore, observations for winter color cannot be considered as a quantitative tool. However, for the purposes of the current study, these data provide evidence to establish that there is considerable variation in winter foliage color among japanese-cedar cultivars.

Flow cytometry. Approximately $240 \mathrm{mg}$ $\left(1 \mathrm{~cm}^{2}\right)$ of young leaf tissue from each japanese-cedar clone and $0.5 \mathrm{~cm}^{2}$ of leaf tissue of Pisum sativum L. 'Ctirad' were simultaneously chopped with a razor blade in a $35 \times 10$-mm petri dish with $400 \mu \mathrm{L}$ of nuclei extraction buffer $\left(\mathrm{CyStain}{ }^{\circledR}\right.$ ultraviolet Precise P Nuclei Extraction Buffer; Partec, Münster, Germany). The solution was filtered using Partec CellTrics ${ }^{\circledR}$ disposable filters with a pore size of $30 \mu \mathrm{m}$ to remove leaf tissue. Nuclei were stained with $1.6 \mathrm{~mL}$ of DAPI staining buffer (CyStain ${ }^{\circledR}$ ultraviolet Precise P Staining Buffer; Partec) and were incubated for $10 \mathrm{~min}$ at $25{ }^{\circ} \mathrm{C}$. The suspension was analyzed using a flow cytometer $\left(\right.$ CyFlow $^{\circledR}$ Ploidy Analyzer; Partec) to determine mean relative DNA fluorescence [mean relative fluorescence (MRF)]. Ploidy and genome size were determined by comparing the MRF of each sample with the $2 \mathrm{C}$ peak of the internal standard [Pisum sativum L. 'Ctirad' $2 \mathrm{C}=8.76 \mathrm{pg}$ (Greilhuber et al., 2007)]. For all samples, at least 1000 particles were analyzed with the exception of 'Araucarioides', 'Atawhai', 'Gyokomo', 'Koshyi', 'Little Diamond', var. sinensis UGA, 'Weed's Dwarf', and 'Yaku', for which fewer than 1000 particles were analyzed. Three samples from each accession were analyzed and data were subjected to analysis of variance and means were separated using Tukey's honestly significant difference test $(\alpha=0.05)$

Cytology. Plants of selected cultivars were placed in flats containing perlite, and roots were allowed to grow out of pots for collection. 
Table 1. Source and relative genome size of Cryptomeria japonica taxa based on flow cytometry of $4^{\prime}, 6-$ diamidino-2-phenylindole-stained nuclei using Pisum sativum 'Ctirad' $(2 \mathrm{C}=8.76 \mathrm{pg})$ as an internal standard.

\begin{tabular}{|c|c|c|c|}
\hline Cultivar/selection & Source & $\begin{array}{c}\text { Winter } \\
\text { foliage color }^{2}\end{array}$ & $\begin{array}{l}\text { Relative } 2 \mathrm{C} \\
\text { genome size }\end{array}$ \\
\hline Araucarioides & Atlanta Botanical Garden & Brown & $19.83 \mathrm{abc}^{\mathrm{y}}$ \\
\hline Atawhai & Atlanta Botanical Garden & - & $19.32 \mathrm{abc}$ \\
\hline Beaumont's Dwarf & Atlanta Botanical Garden & - & $20.52 \mathrm{abc}$ \\
\hline Benjamin Franklin & JC Raulston Arboretum & Dark green & $20.90 \mathrm{abc}$ \\
\hline Black Dragon & Atlanta Botanical Garden & Dark green & $19.63 \mathrm{abc}$ \\
\hline Cristata & Hopper Bros. Nursery & Brown & $19.43 \mathrm{abc}$ \\
\hline Dacrydioides & JC Raulston Arboretum & Purplish red & $22.24 \mathrm{a}$ \\
\hline Egmont & Atlanta Botanical Garden & - & $19.38 \mathrm{abc}$ \\
\hline Elegans & Hopper Bros. Nursery & Bronze to purplish red & $20.74 \mathrm{abc}$ \\
\hline Elegans & Youngblood Nursery & Bronze to purplish red & $21.18 \mathrm{abc}$ \\
\hline Elegans Aurea & Youngblood Nursery & Greenish yellow & $19.66 \mathrm{abc}$ \\
\hline Elegans Nana & Atlanta Botanical Garden & Bronze to purplish red & $19.82 \mathrm{abc}$ \\
\hline Gyokumo & Atlanta Botanical Garden & Medium green & $19.48 \mathrm{abc}$ \\
\hline Gracillis & JC Raulston Arboretum & Greenish-yellow & $20.08 \mathrm{abc}$ \\
\hline Gyokuryu (= Gyokumo) & Atlanta Botanical Garden & Medium green & $19.51 \mathrm{abc}$ \\
\hline Jindai-sugi & Bizon Nursery & Bronze & $20.79 a b c$ \\
\hline Kilmacurragh & JC Raulston Arboretum & Bronze & $20.53 \mathrm{abc}$ \\
\hline Knaptonensis & Atlanta Botanical Garden & Bronze & $19.44 a b c$ \\
\hline Koshyi & Atlanta Botanical Garden & - & $19.95 \mathrm{abc}$ \\
\hline Kusari (= Spiraliter & JC Raulston Arboretum & Light green & $20.35 \mathrm{abc}$ \\
\hline Little Diamond & Atlanta Botanical Garden & Medium green & $19.42 \mathrm{abc}$ \\
\hline Littleworth Dwarf & Atlanta Botanical Garden & Bronze & $21.81 \mathrm{abc}$ \\
\hline Lobbii & JC Raulston Arboretum & Brown & $22.12 \mathrm{ab}$ \\
\hline Monstrosa & JC Raulston Arboretum & Bronze & $20.40 \mathrm{abc}$ \\
\hline Mushroom & Youngblood Nursery & - & $20.16 \mathrm{abc}$ \\
\hline Nana & JC Raulston Arboretum & Bronze to purplish red & $20.43 a b c$ \\
\hline Ogen & Atlanta Botanical Garden & - & $20.00 \mathrm{abc}$ \\
\hline Ogon (= Aurea) & Atlanta Botanical Garden & Bronze & $21.13 \mathrm{abc}$ \\
\hline Oye Keme & Atlanta Botanical Garden & - & $19.66 \mathrm{abc}$ \\
\hline Pygmea & Youngblood Nursery & - & $20.81 \mathrm{abc}$ \\
\hline Pyramidata & Atlanta Botanical Garden & - & $19.30 \mathrm{abc}$ \\
\hline Radicans & JC Raulston Arboretum & - & $20.19 a b c$ \\
\hline Rasen (Spiralis) & Atlanta Botanical Garden & Medium green & $20.65 \mathrm{abc}$ \\
\hline $\begin{array}{l}\text { Rein's Dense Jade } \\
\text { (= Bloomers Witches Broom) }\end{array}$ & Bizon Nursery & Medium green & $19.24 \mathrm{abc}$ \\
\hline $\begin{array}{l}\text { Rein's Dense Jade } \\
\text { (= Bloomers Witches Broom) }\end{array}$ & Atlanta Botanical Garden & Medium green & $20.11 \mathrm{abc}$ \\
\hline Ryocogu Coyokyo & Youngblood Nursery & - & $19.81 \mathrm{abc}$ \\
\hline Sekkan & Hopper Bros. Nursery & Light green & $19.37 \mathrm{abc}$ \\
\hline Sekkan & Youngblood Nursery & Light green & $20.61 \mathrm{abc}$ \\
\hline Selaginoides & Atlanta Botanical Garden & - & $20.09 \mathrm{abc}$ \\
\hline Spiralis & JC Raulston Arboretum & Medium green & $20.14 a b c$ \\
\hline Spiraliter Falcata & Atlanta Botanical Garden & Light green & $19.73 \mathrm{abc}$ \\
\hline Taisho-tama & Atlanta Botanical Garden & Brown & $19.45 \mathrm{abc}$ \\
\hline Tansu (revert) & Atlanta Botanical Garden & - & $20.11 \mathrm{abc}$ \\
\hline Tansu (sport) & Atlanta Botanical Garden & - & $19.35 \mathrm{abc}$ \\
\hline Tenzan & Atlanta Botanical Garden & Dark green & $19.33 \mathrm{abc}$ \\
\hline var. sinensis (JCRA clone) & Atlanta Botanical Garden & - & $18.92 \mathrm{c}$ \\
\hline var. sinensis (weeping form) & Atlanta Botanical Garden & - & $20.19 \mathrm{abc}$ \\
\hline var. sinensis (UGA clone) & Atlanta Botanical Garden & - & $19.84 \mathrm{abc}$ \\
\hline Vilmoriniana & Youngblood Nursery & Bronze & $21.73 a b c$ \\
\hline Viridis & Atlanta Botanical Garden & - & $22.30 \mathrm{a}$ \\
\hline Weed's Dwarf & Atlanta Botanical Garden & - & $19.02 \mathrm{bc}$ \\
\hline Wintermint & Atlanta Botanical Garden & - & $19.61 \mathrm{abc}$ \\
\hline Yaku & Atlanta Botanical Garden & - & $19.33 a b c$ \\
\hline Yellow Twig & JC Raulston Arboretum & - & $20.44 \mathrm{abc}$ \\
\hline Yokohama & Atlanta Botanical Garden & - & $19.83 \mathrm{abc}$ \\
\hline Yoshino & Ron Determann Farm & Bronze & $19.42 \mathrm{abc}$ \\
\hline
\end{tabular}

${ }^{\mathrm{x}}$ From Rouse et al. (2000).

${ }^{y}$ Means within column followed by the same letters are not significantly different based on Tukey's honestly significant difference $(\alpha=0.05)$.

Cytology was conducted as described by Contreras et al. (2010). Chromosomes were visualized using a Carl Zeiss AxioImager (Carl Zeiss MicroImaging GmbH, Jena, Germany). Images were captured using an AxioCam MRm (Carl Zeiss MicroImaging $\mathrm{GmbH})$ and processed using AxioVision FRET software Version 4.7.2 (Carl Zeiss MicroImaging $\mathrm{GmbH})$. Chromosomes of at least 10 cells of however, we attribute this to variation commonly observed during flow cytometry and not to actual differences in chromosome number or ploidy level. The mean holoploid DNA content for all accessions was $20.1 \mathrm{pg}$ and the $\mathrm{CV}$ percentage was $8.5 \%$ or less. One would expect to observe values near $30 \mathrm{pg}$ for triploids and $40 \mathrm{pg}$ for tetraploids; however, the observed values ranged from $18.9 \mathrm{pg}$ for var. sinensis JCRA to 22.3 pg for 'Viridis'. The three accessions with the largest genome sizes, 'Dacrydioides', 'Lobbii', and 'Viridis', were significantly larger than the smallest, var. sinensis JCRA and 'Weed's Dwarf'. There are limitations to calculating genome size when staining with DAPI, which binds preferentially to AT-rich regions of DNA; therefore, our genome size estimates are less exact than when using a DNA intercalator such as propidium iodide. However, DAPI has been shown to be effective and more cost-efficient in analysis of ploidy levels and our results are consistent with Hizume et al. (2001) who reported $22.1 \mathrm{pg} /$ $2 \mathrm{C}$ for japanese-cedar using propidium iodide.

Chromosome counts were performed on 'Ogon' $(2 \mathrm{C}=21.1 \mathrm{pg})$, 'Oye Keme' $(2 \mathrm{C}=$ $19.7 \mathrm{pg}$ ), and 'Viridis' ( $2 \mathrm{C}=22.3 \mathrm{pg}$ ). Based on flow cytometry, these cultivars had statistically different genome sizes; however, all were found to be diploids $(2 n=2 x=22)$ (Fig. 1). Eckenwalder (2009) reported that some of the variable forms in cultivation have one or two extra sets of chromosomes. However, no cultivars were named and it is unclear if the reference is to the chance triploids and tetraploids found in Japan (Chiba, 1951) or specific cultivars with which the author was familiar. In contrast to reports of a base number of 11 for Cryptomeria japonica (Khoshoo, 1961; Sax and Sax, 1933), Dark (1932) reported a base chromosome number of 12 , which is common in other genera of conifers. The report by Dark (1932) is the only report of a base chromosome number differing from 11 for japanese-cedar and appears to be an error. Based on flow cytometry, we thought that 'Viridis' might be an aneuploid (e.g., $2 n+2$ ) because it was among the cultivars with a genome size statistically different from the majority of cultivars in the study. However, cytological analysis revealed that it too is diploid (Fig. 1C).

Polyploids of japanese-cedar, tetraploids in particular, are reported to remain green during winter as a result of increases of up to six times the activity of specific antioxidant enzymes such as superoxide dismutase (Niwa and Sasaki, 2003). In an attempt to exploit this phenomenon to develop new ornamental cultivars, induced tetraploids have been developed (Contreras et al., 2010); however, it remains to be seen if the same gains in antioxidant activity and improved winter color will be observed as in previous studies. In addition to Rouse et al. (2000), Dirr (2009) and Krüssman (1985) reported on the variability in winter foliage color among japanesecedar cultivars, including a number that were included in the current study. There has not been a comprehensive evaluation of cultivars 

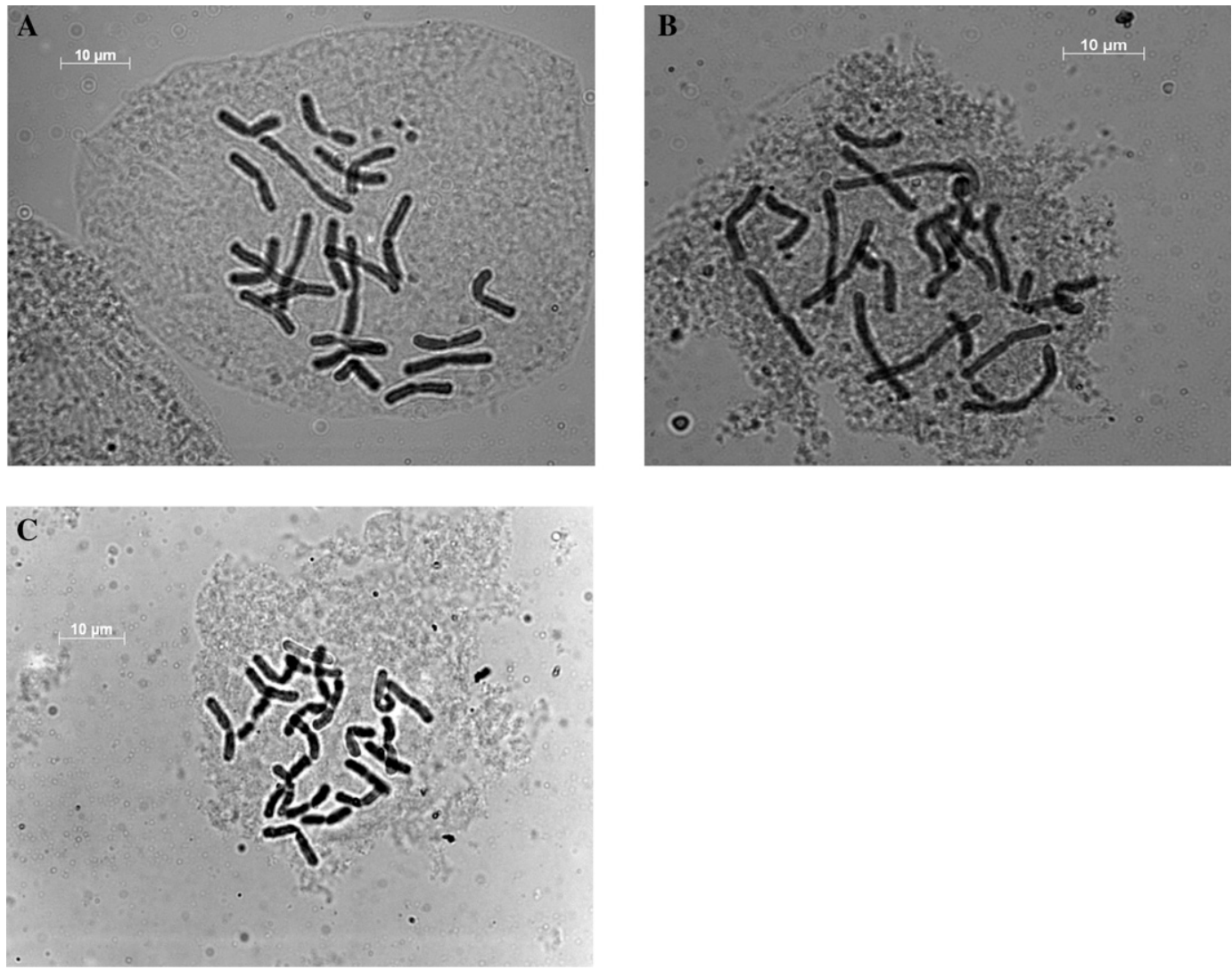

Fig. 1. Photomicrographs of chromosome spreads from root tip squashes of Cryptomeria japonica 'Oye Keme' (A), 'Ogon' (B), and 'Viridis' (C) stained with carbol fuchsin. All cultivars were diploid $(2 n=2 x=22)$.

of japanese-cedar under standardized conditions to compare winter foliage color between cultivars; however, it is well established that differences exist.

We report the analysis of 56 accessions of japanese-cedar for ploidy level and genome size using flow cytometry. Cytological analysis of selected cultivars supported the findings obtained by flow cytometry and all accessions were found to be diploid $(2 n=2 x=22)$. The cultivars and selections included in the current study vary widely in growth form, morphology, and winter browning. Rouse et al. (2000) reported varying winter foliage color (Table 1) for 33 of the accessions included in the current study from brown to dark green. Although not standardized, their report highlights the fact that variability in winter foliage color exists among japanese-cedar cultivars. Some cultivars can be expected to remain greener during winter than others. The underlying cause of this variability is unclear, but it is not related to differences in ploidy level.

\section{Literature Cited}

Chiba, S. 1951. Triploids and tetraploids of sugi (Cryptomeria japonica D. Don) selected in the forest nursery. Bul. Govt. For. Expt. Sta. (Tokyo) 49:99-109.
Contreras, R.N., J.M. Ruter, and B.M. Schwartz. 2010. Oryzalin-induced tetraploidy in Cryptomeria japonica (Cupressaceae). HortScience 45: 316-319.

Dallimore, W. and A.B. Jackson. 1967. A handbook of Coniferae including Ginkgoaceae. 4th Ed. E. Arnold, London, UK.

Dark, S.O.S. 1932. Chromosomes of Taxus, Sequoia, Cryptomeria and Thuya [sic]. Ann. Bot. (Lond.) 46:965-977.

Dirr, M.A. 2009. Manual of woody landscape plants. 6th Ed. Stipes Publ., Champaign, IL.

Eckenwalder, J.E. 2009. Conifers of the world. Timber Press, Portland, OR.

Farjon, A., N. Tien Hiep, D.K. Harder, P. Ke Loc, and L. Averyanov. 2002. A new genus and species in Cupressaceae (Coniferales) from northern Vietnam, Xanthocyparis vietnamensis. Novon 12:179-189.

Greilhuber, J., E.M. Temsch, and J.M. Loureiro. 2007. Nuclear DNA content measurement, $p$. 67-101. In: Dolezěl, J., J. Greilhuber, and J. Suda (eds.). Flow cytometery with plant cells: Analysis of genes, chromosomes and genomes. Wiley-VCH, Weinheim, Germany.

Han, Q., K. Shinohara, Y. Kakubari, and Y. Mukai. 2003. Photoprotective role of rhodoxanthin during cold acclimation in Cryptomeria japonica. Plant Cell Environ. 26:715-723.

Hizume, M., T. Kondo, F. Shibata, and R. Ishizuka. 2001. Flow cytometric determination of genome size in the Taxodiaceae, Cupressaceae senso stricto and Sciadopityaceae. Cytologia (Tokyo) 66:307-311.

Ida, K. 1981. Eco-physiological studies on the response of taxodiaceous conifers to shading, with special reference to the behaviour of leaf pigments. I. Distribution of carotenoids in green and autumnal reddish brown leaves of Gymnosperms. Bot. Mag. Tokyo 94:41-54.

Khoshoo, T.N. 1961. Chromosome numbers in gymnosperms. Silvae Genet. 10:1-9.

Krüssman, G. 1985. Manual of cultivated conifers. Timber Press, Portland, OR.

Niwa, Y. and Y. Sasaki. 2003. Plant self-defense mechanisms against oxidative injury and protection of the forest by planting trees of triploids and tetraploids. Ecotoxicol. Environ. Saf. 55: $70-81$.

Rouse, R.J., P.R. Fantz, and T.E. Bilderback. 2000 Descriptions and a key to cultivars of japanese cedar cultivated in the eastern United States. HortTechnology 10:252-266.

Sax, K. and H.J. Sax. 1933. Chromosome number and morphology in the conifers. J. Arnold Arbor. 14:356-375.

Tripp, K.E. 1993. Sugi: The ancient Japanese cedar finds new life in a profusion of outstanding cultivar forms. Amer. Nurseryman 178: 26-39.

Tripp, K.E. and J.C. Raulston. 1992. Cryptomeria evaluations at the NCSU Arboretum. Proc. 37th Ann. Southern Nurs. Assoc. Res. Conf. 37: 336-339. 